\title{
Energy Use in Agriculture Sector: Input-Output Analysis
}

\author{
Hussain Ali Bekhet (Corresponding Author) \\ College of Business Management \& Accounting \\ Universiti Tenaga Nasional (UNITEN), 26700 Muadzam Shah, Pahang, Malaysia \\ Tel: 60-9-455-2020 ext.2049/Fax: 60-9-455-2006 E-mail: profhussain@uniten.edu.my \\ Azlina Abdullah \\ College of Business Management \& Accounting, \\ Universiti Tenaga Nasional (UNITEN) \\ 26700 Muadzam Shah, Pahang, Malaysia
}

Tel: 60-9-455-2020 ext.3321/Fax: 609-4552006 E-mail: azlina@uniten.edu.my

The research is financed by Universiti Tenaga Nasional

\begin{abstract}
Many sectors rely on energy as input to produce output. Even though the use of energy in agriculture sector is not as high as in other sectors, it is important to study the connectedness between the two sectors as there is no study done so far to show the linkages between them in Malaysia. Input-output analysis has been used to study the connectedness degree between the two sectors using input-output data for 1991-2000. The direct and total backward linkages analyses have shown that there is a significant increase in the use of energy in agriculture sector for the 1991-2000 period but the connectedness is still weak. Among the three energy-related sectors namely; crude oil, natural gas \& coal, petrol \& coal industries and electricity \& gas, it was found that the agriculture sector depends more on inputs from petrol \& coal industries as compared to the other two sectors. Based on these results, some policy implications have been proposed to help the decision-makers in economic planning especially on implementing policies related to energy and agriculture sectors.
\end{abstract}

Keywords: Input-Output, Linkages, Connectedness, Energy, Agriculture

\section{Introduction}

Malaysia has transformed itself since the 1970s from a producer of raw materials into an emerging multi-sector economy. For decades, the agriculture sector has been one of the economic pillars of the country, playing its role as a means for the development of remote and rural areas. It supplies food to the increasing population, reducing the dependence on import for food from abroad and at the same time become a source of national income through its exports, especially products produced from commodities such as oil palm and rubber. Most developing countries experience a declining contribution of agriculture sector to economic growth as they focusing on improving the performance of manufacturing and services sectors as the main contributors to economic development. However, since early 2008, in response to the global food crisis, especially for rice, securing adequate food supply has been one of the top agenda of these countries. Within 5 years, Malaysia's food import bill jumped by 80\% from RM12billion in 2002 to RM23billion in 2007 (DOSM, 2007). The government has allocated RM5.6billion for the implementation of National Food Security Policy from 2008 to 2010. This allocation, among others, is to provide incentives to agriculture entrepreneurs to reduce production costs and encourage higher agriculture output (Malaysia's Budget 2009). Despite the fact that the contribution of agriculture sector to gross domestic product (GDP) is not as high as the contribution of services and manufacturing sectors, it is undeniable that agriculture sector play a very important role in economic development and sustaining the welfare of society. Figure 1 shows the contribution of each sector to GDP. The main contributor to GDP is services sector. It is followed by manufacturing, mining, agriculture and construction sectors. In terms of growth, it is found that the highest growth rate is for mining sector ( 8.7 percent), followed by manufacturing ( 8.39 percent) and services $(7.19$ percent) sectors. The least growth is for agriculture sector (2.66 percent) followed by construction sector (5.23 percent).

The government through its $3^{\text {rd }}$ National Agriculture Policy (1998-2010) is putting efforts to maximize income through the optimal utilization of resources in agriculture sector. The specific objectives of the policy are to enhance food security; to increase productivity and competitiveness of the sector; to deepen interrelationship with other sectors; to create new sources of growth for the sector; and to conserve and utilize natural resources in a sustainable basis. In tandem with government objective through this policy, therefore, it is important to investigate the linkages between agriculture and energy sectors of this country. As all know, energy being the 
capacity to do work is very important for all human activities, especially those concerning the production of goods and services. Furthermore, in addition to the limited supply of non-renewable sources of energy such as crude oil, natural gas and coal, the environmental impact from their usage have attracted the researchers to study the interrelationship between the two sectors in depth. The study on energy use patterns in Malaysia still needs more evidences and analysis. In the literature review, we found very few studies investigated the issues related to the use of energy. There is no study found to investigate the interrelationship between energy sector and agriculture sector.

\section{Objectives of the Study}

There are still very few studies on linkages between economic sectors in Malaysian economy. There is no single study has been done to investigate the linkages between energy and agriculture sectors in this country. It might not be of interest among researchers to discuss issues in agriculture sector as its contribution to economic growth is not as important as the contribution by services and manufacturing sectors. This study has taken an initiative to fill this gap and to take the responsibility to propose any policy implications that seems suitable for policy-makers to implement for the betterment of both agriculture and energy sectors based on the research findings.

The aim of this study is to provide an economic analysis of energy consumption in agriculture sector in Malaysia for the 1991-2000 period using input-output methods. So, the interdependency between agriculture and energy sectors will be analyzed. The direct and total backward linkages between the two sectors will be measured and analyzed. This analysis is important to perform necessary improvements in both sectors. It is expected that this study will help in determining a production system that involves sustainable use of energy in Malaysia's agriculture.

Based on the above-mentioned objectives, the hypotheses of this study could be formalized as follows:

There is a significant connectedness between agriculture and energy sector in Malaysia, on the one hand, and on the other hand, there is a significant change in the use of energy in agriculture sector in Malaysia.

\section{Overview of Energy Sector}

Malaysia is a significant Southeast Asian producer of crude oil and natural gas. Sustained economic growth has helped to make the country a growing energy consumer in its own right. From being an energy rich country a decade ago, Malaysia will gradually be joining other countries that have to rely on imports in order to meet domestic demand. Although blessed with crude oil resources, Malaysia is relatively a small producer at the international level. In fact, the oil and gas reserves are now depleting. In the case of natural gas, the production is declining at the rate of about 10 percent per annum (Ahmad, 2010). As of $1^{\text {st }}$ January 2009, crude oil reserves were at 5.52 billion barrels and natural gas reserves stood at 87.9 trillion cubic feet and sufficient to last for 22 and 36 years respectively based on the current production level (Economic Report, 2009/2010). The growth rates for the production of crude oil, natural gas and electricity for the 1973-2006 period were 5.78, 17.28 and 9.51 percent respectively (See Figure 2).

Besides crude oil and natural gas, Malaysia also has some coal resources. However, due to remoteness and quality factors, only a small percentage of local coal is being mined while a sizeable amount is imported to meet the requirement for power generation (Ahmad, 2010). As of $31^{\text {st }}$ December 2008, Malaysia's coal reserves were at 1938.4 million tonnes (Malaysian Energy Center, 2008). In addition, large hydro resources have also been developed over the years throughout the country but there remains some potential for future development. As for electricity, natural gas continued to remain the main fuel source for its generation followed by coal, hydropower, diesel and fuel oil. The calculated reserve margin for Peninsular Malaysia in 2008 was 43 percent and 13 percent for Sarawak with Sabah at 44 percent (Malaysian Energy Center, 2008).

On the demand side, in meeting increasing energy demand, Malaysia has been importing natural gas from the Malaysia-Thailand Joint Development Area (JDA) and West Natuna, Indonesia. Citing the fuel diversification policy, the country has also been increasing its import for coal so as to reduce its dependence on natural gas and to ensure a balance energy mix for power generation. For energy demand by sectors in 2008, the share in energy demand was highest for the industrial sector, followed by the transportation sector, residential \& commercial sector, the non-energy sector and agriculture sector. Only non-energy use and residential \& commercial sectors showed downward trends in energy demand (Malaysian Energy Center, 2008). Figure 3 shows energy demand by classification of sectors from the viewpoint of Malaysian Energy Centre. For the 1990-2008 period, the energy demand had been dominated by industrial and transportation sectors. Their growth rates were 6.96 percent and 6.54 percent respectively. Since 2007, the energy sector has expanded as expected following the execution of major projects under the $9^{\text {th }}$ Malaysia Plan (Malaysian Energy Center, 2007). 
Malaysia's energy consumption in agriculture sector has increased in recent years. Even though the usage in this sector is relatively small, it is still important to know the pattern of its energy usage in order to help for economic planning for both sectors (i.e agriculture and energy sectors). There are several reasons that might be resulted for increasing energy consumption in agriculture sector. Among the reasons are; the problem of labour shortage within the sector along with government policy to reduce the dependency on foreign labour and the limited availability of land for agricultural activities caused by rapid development for housing and industrial areas. Modernization of agriculture sector by the use of new technology in meeting the increasing demand on agriculture products has also led to increasing energy consumption.

Agriculture activities such as rubber, oil palm, coconut and tea plantations, livestock breeding and poultry, fishing and many others use input from energy sector to produce output. Input such as crude oil, natural gas, coal, petroleum products and electricity are crucial in the production of agriculture output. Table 1 shows that each agriculture activity absorbs an amount of each type of energy as input for its production. The highest amount of energy absorbed by each agriculture activity is from petrol \& coal industries. Among all of the agriculture activities, fishing activity absorbs the highest amount of energy followed by forestry \& logging and oil palm estates. In total, for the year of 2000, agriculture sector absorbs input from energy sector at the amount of near to RM2.5billion. Therefore, it is clear that there is a high connection between agriculture sector and energy sector. This study will investigate in detail on how strong is the connectedness between the two sectors using input-output methods.

\section{Literature Review}

Agriculture requires energy as an important input for production. Energy consumption by the agriculture sector can be broadly categorized into direct and indirect energy use. Agriculture uses energy directly as fuel or electricity to operate machinery and equipment, to heat or cool buildings and for lighting in the farm and indirectly in the fertilizers and chemicals produced off the farm (Uhlin, 1998). Energy's share in agriculture production varies widely by the kind of activities, production practices applied, geographic location of the production area and environmental conditions such as soil and climate factors (Esengun et al., 2007).

The agriculture sector, like other sectors, has become increasingly dependent on energy resources such as electricity, fuels, natural gas and coke. This increase in energy use and its associated increase in capital intensive technology can be partially attributed to low-energy prices in relation to the resource for which it was being substituted (Gowdy et al., 1987). Modernization of many operations in agriculture production increases its energy consumption. In order to sustain agriculture production, effective energy use is required, since it provide financial savings, preservation of fossil resources and reduction in air pollution (Pervanchon et al., 2002 and Pimentel, 1980). In addition, with the limited availability of suitable land for agriculture, the only chance for producers to increase total output will be using more input. The dependence of agriculture sector on energy sector to supply more food to increasing population and considering the limited natural resources, as well as the impact of using energy sources on environment and human health, it is substantial to investigate energy use patterns and energy efficiency in agriculture sector (Hatirli, Ozkan and Fert, 2005).

The analysis of linkages between sectors has a long history within the field of input-output analysis. The input-output analysis and the derivation of linkages indices were initially proposed by Leontief (1936). He considered the various economic sectors as a series of inputs of source materials (or services) and outputs of final or intermediate goods (or services). Rasmussen (1956) then developed the procedures for measuring inter-industry linkages using the inverse of Leontief input-output tables which takes into account both the direct and indirect effects of an increase in the output of an industry. Rasmussen's backward and forward linkages are known as power of dispersion index and sensitivity of dispersion index respectively. Chenery and Watanabe (1958) proposed using the column (or row) sums of the input coefficient matrix to calculate backward and forward linkages. However, this measure only captures direct effects and leaving out indirect impacts. Hirschman (1958) suggested that backward linkages effects are related to derived demand, while forward linkages effects are related to output utilization.

In the 1970s, the above-mentioned traditional measures were widely discussed. They have been improved and expanded in several ways, and many different methods have been proposed for the measurement of linkages coefficients (Hazari, 1970; Yotopoulos \& Nugent, 1973; Laumas, 1976; Riedel, 1976; Jones, 1976; Schultz, 1977). More recently, linkages analysis methods have again attracted increasing attention from input-output analysts (Cella, 1984; Clements, 1990; Heimler, 1991; Sonis et al., 1995; Dietzenbacher \& Linden, 1997). However, each has its own advantages and disadvantages.

The input-output modeling technique has been extensively used in decomposition analyses of sectoral energy consumption. This is mainly because an input-output table conveniently presents an exact quantitative 
relationship between the energy sector and its users. Some recent studies in this regard include Mairet and Decellas (2009), Ray and Reddy (2007), Bhattacharyya and Ussanarassamee (2005), and Mukhopadhyay (2002). Energy input-output analysis is usually used to evaluate the efficiency and environmental impacts of production systems. Considerable studies have been conducted on energy use in agriculture using input-output analysis. For instance, studies done by Esengun et.al (2007); Karkacier \& Goktolga (2005); Uhlin (1998), Sigh et al. (1997) and Franzluebbers \& Fancis (1995). However, among all the studies available, there were very few using input-output tables as their sources of data. Instead, data were collected through survey questionnaires. The researchers of this study will only use data from input-output table which is more suitable for national economic planning as the data representing values aggregated at national level. The study on the interrelationship between the two sectors will be very useful to provide planners and policy-makers an opportunity to evaluate economic interactions between them.

\section{Data and Methodology}

\subsection{Data}

This study uses secondary data from Malaysia's Input-Output Tables for the year 1991 and 2000 which published by the Department of Statistics Malaysia (DOSM). Each table has been aggregated to 15 sectors. Among the 15 sectors there are 3 sectors which are related to energy; crude oil, natural gas \& coal, petrol \& coal industries, and electricity \& gas. Since the researchers are concerned about energy use in agriculture sector, therefore, the 3 energy-related sectors are treated separately and there exists another important sector, namely agriculture. The detailed aggregation is shown in Table 2.

The researchers use Microsoft Excel for the calculation of $\underline{A}$ coefficient matrix, (I-A $)^{-1}$ inverse matrix and for the data analysis process. The period of study is 1991-2000 using the latest two input-output tables published by the Department of Statistics of Malaysia. The latest two tables i.e 1991 and 2000 are chosen for consistency of types of energy-related sectors available in these two tables. In other words, the earliest three tables published for 1978, 1983 and 1987 were ignored since there are inconsistencies in types of energy-related sectors. Data from input-output tables is not of the kind of time-series data. Normally, it is published for every 5 years consecutively. Therefore, the limitation of this study is the failure to investigate the changes in energy consumption using time-series data.

\subsection{Methodology}

Towards the achievement of research objectives, this research will employ method based on Leontief's input-output framework (e.g. Leontief, 1966; Miller \& Blair, 1985) where the structure of an economy is analyzed in terms of connectedness between production sectors. Generally the input-output model which describes the transactions among economic sectors are described through the use of a system of linear equations, which represent for each sector the identity between the total output produced and the output purchased and consumed by all the other sectors of the system. In other words, everything produced by a sector is purchased and consumed respectively by the other ones as inputs or by the consumer as final demand. In matrix notation this system of linear equations is;

$$
\underline{x}=(\underline{I}-\underline{A})^{-1} \underline{f}
$$

Here $\underline{x}$ is a column vector of output of order $n$; $\underline{f}$ is a column vector of final demand of order $n$; $\underline{I}$ represents an identity matrix and $\underline{\mathrm{A}}$ is the coefficient matrix. $(\underline{\mathrm{I}}-\underline{\mathrm{A}})^{-1}$ is known as 'Leontief inverse' matrix. This equation is the solution equation of the input-output analysis.

A study on connectedness between production sectors allows us to identify the most important sectors in an economy. This study will only focus on direct and total backward linkages which allow one to find the dependence of one industry on other industries in terms of the supply of inputs. In other words, it measures the extent to which an industry utilizes the outputs of other industries as input for its production process. In an input-output framework, purchases of industry B from industry A are recorded as B's backward linkages. One possible measure of backward connectedness is known as direct backward linkages which uses the column sum of technical coefficient matrix, $\underline{A}$, as proposed by Chenery (1958). Each value of the $\underline{A}$ matrix is obtained by dividing each entry in the transaction table by its column total i.e the total input coefficient of the respective sector. In other words, the column sum of $\underline{A}$ matrix will be used to measure the backward linkages. The direct backward linkages, $\mathrm{U}_{\mathrm{j}}$, can be calculated by:

$$
\mathrm{U}_{\mathrm{j}}=\sum_{\mathrm{i}=1}^{\mathrm{n}} \mathrm{a}_{\mathrm{ij}}
$$

The above method measures the first round effects generated by the connectedness between sectors since it is based on direct input coefficients, $\underline{A}$. Therefore, these indicators are called direct backward linkages indicators. 
Unfortunately, the measurement on direct backward linkages ignores the indirect stimuli given to the economy if investment takes place. This measure has three deficiencies (Jones, 1976); double counting of causal linkages, neglect of indirect impacts and failure to distinguish the domestic effect from those operating on foreign economies. Therefore, this study will also measure both the direct and indirect linkages i.e total backward linkages using (I- $\underline{\mathrm{A}})^{-1}$ matrix i.e the input inverse and find the sum of each column elements (Yotopoulus and Nugent, 1976). The formula which is used to calculate the total backward index can be written as follows:

$$
\underline{1}_{-j}=\underline{i}(\underline{I}-\underline{A})^{-1}
$$

$\underline{1}_{j}$ is the sum of the elements in column $\mathrm{j}$ of the (I- $\left.\underline{\mathrm{A}}\right)^{-1}$ matrix. Now, each element in column $\mathrm{j}$ measures the direct and indirect impact of the inverse of one unit in the final demand for industry $\mathrm{j}$ on each of the $\mathrm{n}$ industries. It must be noted that Equation (3) would be used also as a multiplier (Bekhet, 2009).

\section{Results Analysis}

Table 3 shows the direct and total backward linkages for Malaysian economic sectors for the year 1991-2000. For direct backward linkages, it is found that light manufacturing and petrol \& coal industries are the most important sectors in the economy in terms of their connectedness with other industries for the period of 1991-2000. With regard to agriculture sector, its performance was at rank number 14 in 1991 but has jumped to rank number 10 in 2000. The value of 0.265 for agriculture sector in year 2000 means 26.5 percent inputs from intermediate demand has been used for the production of agriculture output. That is for each RM1 output produced by agriculture sector, it purchases 0.265 cents as inputs from intermediate demand in the economy such as inputs from petrol \& coal industries, electricity \& gas, water, and inputs produced by its own sector. There is a significant change in the direct backward linkages value for agriculture sector for 1991-2000 period which has increased from 20.4 percent to 26.5 percent.

Also, the results on total backward linkages for Malaysian economy indicate that the communication sector shows the highest total backward linkages (2.062) followed by petrol \& coal industries (2.012) and light manufacturing sector (1.509). After 10 years i.e in 2000, the results have changed which had shown the light manufacturing at the first ranking (1.962) followed by hotel \& restaurants sector (1.715) and buildings \& constructions (1.616). For agriculture sector, its ranking has improved from number 14 (1.336) in 1991 to number 8 (1.406) in 2000. This results show that the connectedness of agriculture sector with other sectors has become stronger after the 10 years duration.

Table 4 shows the direct backward and total backward linkages between agriculture and energy-related sectors namely crude oil, natural gas $\&$ coal, petrol \& coal industries and electricity $\&$ gas. In terms of direct backward linkages, it is shown that, among the three energy-related sectors, agriculture sector was relying more on petrol $\&$ coal industries output as its input compared to the other two energy-related sectors. The value of total energy use in agriculture sector was significantly increased by 440 percent in 2000 where it only used 1 percent of energy as input in 1991 and has jumped to 5.4 percent in 2000. For total backward linkages, petrol \& coal industries remain at the first ranking for both the 1991 and 2000 as the main input of energy for agriculture sector. However, the ranks for crude oil, natural gas \& coal and electricity \& gas have interchanged between one another as the second and third rank in terms of supplying inputs to agriculture sector.

Finally, it can be concluded that within 10 years duration, agriculture sector connectedness with other sectors in the economy has become stronger. Its dependence on overall sectors in the economy to supply inputs for its production has increased. However, from the perspective of input-output analysis, the connectedness is still weak as all the values are below 0.5. Furthermore, there is a significant increase in the use of energy inputs by agriculture sector in terms of both direct and total backward linkages. Among the three energy-related sectors, it relies more on inputs from petrol \& coal industries. However, again, from the input-output analysis point of view, the connectedness between agriculture and each of energy-related sectors is still weak. Thus, from the above results, the two hypotheses stated earlier can be accepted. Also, we can conclude that there is a significant connectedness between agriculture and energy sector and there is a significant change in the use of energy in agriculture sector.

\section{Policy Implications}

As shown by the above results, the linkages between agriculture and energy sectors have become stronger especially agriculture linkages with petrol and coal industries. As referred to the input-output table of Malaysia for the year 2000, the agriculture subsector which absorbed the highest amount of petrol \& coal products was fisheries sector followed by forestry \& logging and oil palm estates. Malaysia government has been implementing fuel subsidy system since 2002 and has been restructuring the system for several times to ensure the subsidy to reach the target group and preventing irresponsible parties from abusing the subsidy through 
smuggling of the commodity i.e fuel. Selecting those involved in fisheries sector as among the recipients of the subsidy is the right decision made by Malaysia government. However, the problem of fuel i.e petrol and diesel smuggling into neighboring countries especially Thailand and the problem of abusing the subsidy system are still rampant. Therefore, the government should take appropriate steps to curb these problems seriously.

The result had shown that the values of direct backward linkages between agriculture sector and electricity $\&$ gas sector between 1991 and 2000 are the same. It means the linkages between the two are stagnant after 10 years duration. This paper recommends that the use of electricity and gas as inputs in agriculture sector should be increased wherever possible as their costs are cheaper compared to petrol products and this will result in increasing profits in that sector. This will indirectly benefit those low and middle income families by earning higher income compared to their earnings when using petrol products as inputs for agriculture production activities.

\section{Conclusion and recommendation}

This study has explored the direct and total backward linkages between all sectors in Malaysian economy and later emphasis the linkages between agriculture and energy sectors. Furthermore, it can be indicated that there is a connectedness between agriculture and energy sector in the Malaysian economy. It is also found that there is an increase in the connectedness between the two sectors for the 1991-2000 period. If we are comparing between the three energy-related sectors namely; crude petrol, natural gas \& coal, petrol \& coal industries and electricity $\&$ gas, the results show that agriculture sector depends more on petrol \& coal industries products as inputs for its production process. For more evidence of the policy implication, we recommended that it might be suitable to be taken into consideration by policymakers to further enhance the linkages between sectors in Malaysia especially between agriculture and energy sectors by using multipliers indicators.

\section{References}

Ahmad, N. (2010). "The Malaysia's Energy Sector: In Pursuit of A Better Future”, Economic Planning Unit, Malaysia, available online at http://www.epu.gov.my/.

Al-Amin, A.Q., Siwar, C., Jaafar, A.H. and Hossain, M.E. (2007). "Energy Use in Transportation Sector and Pollution Implications for the Malaysian Economy", Paper for Singapore AERC Conference, 2007, Singapore.

Al-Amin, A.Q., Siwar, C., Jaafar, A.H., and Huda, N. (2007). "Pollution Implications of Electricity Generation in Malaysian Economy: An Input-Output Approach", Paper for Singapore AERC Conference, 2007, Singapore.

Bekhet, H.A. (2009). Decomposition of Malaysian Production Structure: Input-Output Approach, International Business Research, Vol.2, No.4, pp.152-162.

Bekhet, H.A. (2009). Mathematical Models and Assessing the Success of the Development Policies for Malaysian Economy, Professorial lecture series, PLS3, Universiti Tenaga Nasional (UNITEN). Malaysia.

Bekhet, H.A. (2010). Output, Income and Employment Multipliers in Malaysian economy: input-output approach, paper still under processing.

Bekhet, H.A. (2009). “Assessing Economic Connectedness Degree of the Malaysian Economy: Input-Output Model Approach," International Journal of Economics and Finance, Vol.1, no.2, pp.134-143.

Bhattacharyya, S.C., and Ussanarassamee, A. (2005). "Changes in Energy Intensities of Thai Industry between 1981 and 2000 : A Decomposition Analysis”, Energy Policy, 33, pp.995-1002.

Cella, G. (1984). "The Input-Output Measurement of Interindustry Linkages", Oxford Bulletin of Economics and Statistics, 46 (1), pp.73-84.

Chakraborty, D. (2007). "A Structural Decomposition Analysis of Energy Consumption in India". Paper submitted for the $16^{\text {th }}$ International Input-Output Conference, 2-6 July, 2007, Istanbul, Turkey.

Chenery, H.B. and Watanabe, T. (1958). "International Comparisons of the Structure of Production", Econometrica, 26 (4), pp. 487-521.

Clements, B.J. (1990) "On the Decomposition and Normalisation of Interindustry Linkages," Economics Letters, 33, pp.337-40

Department of Statistics, Malaysia, (1988), Input-Output Tables Malaysia 1983.

Department of Statistics, Malaysia, (1994), Input-Output Tables Malaysia 1987.

Department of Statistics, Malaysia, (2002), Input-Output Tables Malaysia 1991.

Department of Statistics, Malaysia, (2005), Input-Output Tables Malaysia 2000. 
Department of Statistics, Malaysia. (2005). Annual National Account, Gross Domestic Product (GDP) 1987-2004.

Department of Statistics, Malaysia. (2009). Annual National Account, Gross Domestic Product (GDP) 2000-2008.

Department of Statistics, Malaysia. (2009). Yearbook of Statistics Malaysia 2008.

Department of Statistics, Malaysia. (2007). Malaysia Economic Statistics-Time Series.

Dietzenbacher,E., and Van Der Linden, J. (1997). "Sectoral and Spatial Linkages in the EC Production Structure", Journal of Regional Science, 37 (2), pp. 235-257.

Esengun, K., Erdal, G., Gunduz, O., and Erdal, H. (2007). "An Economic Analysis and Energy Use in Stake-Tomato Production in Tokat Province of Turkey", Renewable Energy 3, pp. 1873-1881.

Esengun, K., Gunduz, O., and Erdal, G. (2007). "Input-Output Energy Analysis in Dry Apricot Production of Turkey”, Energy Converse Management 48, pp.592-598.

Franzluebbers, A.J., and Francis, C.A. (1995). "Energy Output-Input Ratio of Maize And Sorghum Management Systems in Eastern Nebraska", Agriculture Ecosystem Environment, 53(3), pp.271-8.

Gowdy, J.M., Miller, J.L. and Kherbachi, H. (1987). "Energy Use in US Agriculture", Southern Journal of Agricultureal Economics, 19(2), pp.33-41.

Haji, J.A. (1987). "Key Sectors and the Structure of Production in Kuwait - An Input-Output Approach", Applied Economics, 19(9), pp.1187-1200.

Hatirli, S.A., Ozkan, B. and Fert, C. (2005). "An Econometric Analysis of Energy Input-Output in Turkish Agriculture”, Renewable and Sustainable Energy Reviews, 9, pp.608-623

Hazari, B.R. (1970). "Empirical Identification of Key Sectors in the Indian Economy", The Review of Economics and Statistics, 52 (3), pp.301-305.

Heimler, A. (1991). "Linkage and Vertical Integration in the Chinese Economy", Review of Economics and Statistics, 73, pp.261-267.

Hirschman, A.O. (1958). Interdependence and Industrialization. The Strategy of Economic Development. Yale University Press, New York.

Jaafar, A.H., Al-Amin, A.Q. and Siwar, C. (2006). "Environmental Impact of Alternative Fuel Mix in Electricity Generation in Malaysia", Paper presented at the 1st Malaysian Economic Conference. Malaysia, Port Dickson, 11-13 December, 2006.

Jones, L.P. (1976). “The Measurement of Hirschman Linkages”, Quarterly Journal of Economics, 90 (2), pp. 323-333.

Karkacier, O., and Goktolga, G. (2005). "Input-Output Analysis of Energy Use in Agriculture", Energy Conversion and Management, 46, pp.1513-1521.

Laumas, P.S. (1976). "The Weighting Problem in Testing the Linkage Hypothesis", Quarterly Journal of Economics, 90(2), pp. 308-312.

Leontief, W. (1936). Input-output Economics. New York, Oxford University Press, 1966.

Mairet, N., and Decellas, F. (2009). "Determinants of Energy Demand in the French Service Sector: A Decomposition Analysis.”, Energy Policy, 37, pp.2734-2744.

Malaysia Energy Centre. (2009). National Energy Balance 2007.

Malaysia Energy Centre. (2010). National Energy Balance 2008.

Miller, R.E., and Blair, P.D. (1985). Input-Output Analysis: Foundations and Extensions. Prentice Hall, New Jersey.

Ministry of Agriculture, Third National Agriculture Policy, available online at http://www.moa.gov.my/dpn3.

Ministry of Finance, Malaysia, Economic Report 2009/2010, available online at http://www.treasury.gov.my/.

Ministry of Finance, Malaysia, The 2009 Budget Speech, available online at http://www.treasury.gov.my/pdf/budget/bs09.pdf. 
Mukhopadhyay, K. (2002) "An Input-Output Study of the Relationship between Information Sector, Energy Use $\& \mathrm{Co}_{2}$ Emission in the Indian Economy During 1973-74 to 1996-97”, Paper submitted for the $14^{\text {th }}$ International Conference on Input-Output Technique held at University of Quebec, Montreal ,Canada Oct 10-15, 2002.

Ozkan, B., Akcaoz, H., and Fert, C. (2004). "Energy Input-Output Analysis in Turkish Agriculture", Renewable Energy, 29, pp.39-51.

Pervanchon, F., Bockstaller, C. and Girardin, P. (2002) "Assessment of Energy Use in Arable Farming Systems by Means of an Agro-Ecological Indicator: The Energy Indicator." Agriculture System, 72:pp.149-72.

Pimentel, D. (1980). Handbook of Energy Utilization in Agriculture. Boca Raton, FL: CRC Press.

Rasmussen, N.P. (1956). Studies in Inter-Sectoral Relations. Amsterdam, North Holland.

Ray, B.K., and Reddy, B.S. (2007). "Decomposition of Energy Consumption and Energy Intensity in Indian Manufacturing Industries". Indira Gandhi Institute of Development Research, Mumbai, India, available online at http://www.igidr.ac.in/pdf/publication/WP-2007-020.pdf.

Riedel, J. (1976). "A Balanced-Growth Version of the Linkage Hypothesis: A Comment", Quarterly Journal of Economics, XC, pp.319-22.

Saari, M.Y., and Rashid, Z.A. (2006). "The Impact of Increase in Petroleum Prices on Costs of Production of The Malaysian Economy", International Journal of Economics and Management, 1(1), pp.25-41.

Saari, M.Y., and Rashid, Z.A. (2007). "The Impact of Increase in Energy Prices on Sectoral Costs of Production of The Malaysian Economy", International Journal of Management Studies, 14(2), pp.75-91.

Schultz, S. (1977). "Approaches to Identifying Key Sectors Empirically by Means of Input-output Analysis", Journal of Development Studies, 14 (1), October, pp.77-96.

Singh, M.K., Pal, S.K., Thakur, R. and Verma, U.N. (1997). "Energy Input-Output Relationship of Cropping Systems", Indian Journal of Agriculture Science, 67(6), pp. 262-266.

Sonis, M., Guilhoto, J.J.M., Hewings, G.J.D. and Martins, E.B. (1995). "Linkages, Key Sectors, and Structural Change: Some New Perspective”, The Developing Economies, XXXIII (3), pp.233-270.

Uhlin, H.E. (1998). "Why Energy Productivity is Increasing: An I-O Analysis of Swedish Agriculture." Agricultural Systems, Vol.56, No.4, pp.443-465.

Yotopoulos, P.A. and Nugent, J.B. (1973). "A Balanced-Growth Version of the Linkage Hypothesis: A Test", The Quarterly Journal of Economics, LXXXVII (2), pp.157-171.

Yotopoulos, P.A. and Nugent, J.B. (1976).'In Defense of A Test of the Linkage Hypothesis", Quarterly Journal of Economics, Vol.90, pp.33-343.

Table 1. Absorption of Domestic Energy Production by Agriculture Activities at Basic Values, 2000 (RM '000)

\begin{tabular}{|c|c|c|c|c|c|c|c|c|c|}
\hline & 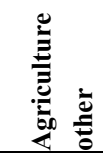 & 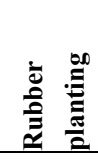 & 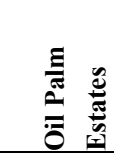 & 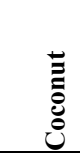 & 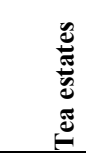 & 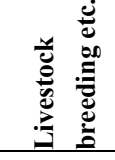 & 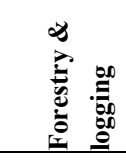 & 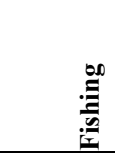 & है \\
\hline $\begin{array}{l}\text { Crude oil, Natural gas } \\
\& \text { Coal }\end{array}$ & 1,494 & 264 & 4,769 & 17 & 5 & 3,612 & 5,184 & 1,015 & 16,360 \\
\hline $\begin{array}{l}\text { Petrol \& Coal } \\
\text { industries }\end{array}$ & 66,740 & 3,120 & 483,994 & 42 & 482 & 60,895 & 784,507 & 939,544 & $2,339,324$ \\
\hline Electricity \& Gas & 3,520 & 3,624 & 22,701 & 183 & 263 & 22,813 & 1,217 & 44,542 & $\mathbf{9 8 , 8 6 3}$ \\
\hline Total & 71,754 & 7,008 & 511,464 & 242 & 750 & 87,320 & 790,908 & 985,101 & $2,454,547$ \\
\hline
\end{tabular}

Source: DOSM (2005), Input-Output Table for 2000, Malaysia. 
Table 2. Aggregation of Sectors

\begin{tabular}{|l|c|}
\hline \multicolumn{1}{|c|}{ Sector } & Input-Output Tables \\
\cline { 2 - 2 } & $\mathbf{1 9 9 1 - 2 0 0 0}$ \\
\hline 1. Agriculture & $1-8$ \\
\hline 2. Crude oil, natural gas \& coal & 9 \\
\hline 3. Other mining \& quarrying & 10,11 \\
\hline 4. Light manufacturing & $12-36$ \\
\hline 5. Heavy manufacturing & $37-41,43-65$ \\
\hline 6. Petroleum \& coal products & 42 \\
\hline 7. Electricity \& gas & 66 \\
\hline 8. Water & 67 \\
\hline 9. Buildings \& constructions & 68 \\
\hline 10. Wholesales \& retail trade & 69 \\
\hline 11. Hotel \& restaurant & 70 \\
\hline 12. Transport & 71 \\
\hline 13. Communication & 72 \\
\hline 14. Banks, finance, insurance, real estate \& business services & $73-78$ \\
\hline 15. Other services & $79-94$ \\
\hline
\end{tabular}

Table 3. Direct Backward and Total Backward Linkages

\begin{tabular}{|c|c|c|c|c|c|c|c|c|}
\hline \multirow{3}{*}{ Sector } & \multicolumn{4}{|c|}{ Direct Backward Linkages ( $\underline{U} j)$} & \multicolumn{4}{|c|}{ Total Backward Linkages (lj) } \\
\hline & \multicolumn{2}{|c|}{1991} & \multicolumn{2}{|c|}{2000} & \multicolumn{2}{|c|}{1991} & \multicolumn{2}{|c|}{2000} \\
\hline & Value & Rank & Value & Rank & Value & Rank & Value & Rank \\
\hline 1. Agriculture & 0.204 & 14 & 0.265 & 10 & 1.336 & 14 & 1.406 & 8 \\
\hline 2. Crude oil, natural gas \& coal & 0.093 & 15 & 0.066 & 15 & 1.145 & 15 & 1.09 & 15 \\
\hline 3. Other mining \& quarrying & 0.305 & 10 & 0.307 & 7 & 1.494 & 11 & 1.445 & 7 \\
\hline 4. Light Manufacturing & 0.583 & 2 & 0.587 & 1 & 1.941 & 3 & 1.962 & 1 \\
\hline 5. Heavy Manufacturing & 0.336 & 7 & 0.266 & 9 & 1.509 & 9 & 1.368 & 10 \\
\hline 6. Petrol \& coal industries & 0.814 & 1 & 0.505 & 2 & 2.012 & 2 & 1.605 & 4 \\
\hline 7. Electricity \& Gas & 0.305 & 9 & 0.270 & 8 & 1.544 & 7 & 1.382 & 9 \\
\hline 8. Water & 0.327 & 8 & 0.421 & 5 & 1.505 & 10 & 1.598 & 5 \\
\hline 9. Buildings \& constructions & 0.413 & 5 & 0.440 & 4 & 1.653 & 5 & 1.616 & 3 \\
\hline 10. Wholes. \& retail trade & 0.288 & 12 & 0.158 & 14 & 1.486 & 12 & 1.233 & 14 \\
\hline 11. Hotel \& restaurant & 0.510 & 4 & 0.444 & 3 & 1.834 & 4 & 1.715 & 2 \\
\hline 12. Transport & 0.358 & 6 & 0.390 & 6 & 1.588 & 6 & 1.589 & 6 \\
\hline 13. Communication & 0.542 & 3 & 0.206 & 12 & 2.062 & 1 & 1.281 & 12 \\
\hline $\begin{array}{l}\text { 14. Banks, Fin., Insurance, } \\
\text { R.Estate, Bus.services }\end{array}$ & 0.286 & 13 & 0.183 & 13 & 1.515 & 8 & 1.249 & 13 \\
\hline 15. Other Services & 0.294 & 11 & 0.245 & 11 & 1.483 & 13 & 1.354 & 11 \\
\hline
\end{tabular}

Source: DOSM, Input-Output Table for $1991 \&$ 2000, Malaysia.

Table 4. Direct and Total Backward Linkages between Agriculture and Energy-Related Sectors

\begin{tabular}{|l|c|c|c|c|c|c|c|c|}
\hline \multirow{2}{*}{ Sector } & \multicolumn{3}{|c|}{ Direct Backward Linkages $(\underline{U})$} & \multicolumn{3}{c|}{ Total Backward Linkages(lj) } \\
\cline { 2 - 11 } & \multicolumn{2}{|c|}{$\mathbf{1 9 9 1}$} & \multicolumn{2}{c|}{$\mathbf{2 0 0 0}$} & \multicolumn{2}{c|}{1991} & \multicolumn{2}{c|}{$\mathbf{2 0 0 0}$} \\
\cline { 2 - 10 } & Value & Rank & Value & Rank & Value & Rank & Value & Rank \\
\hline Crude oil, natural gas \& coal & 0.000 & 3 & 0.000 & 3 & 0.008 & 2 & 0.024 & 2 \\
\hline Petrol \& coal industries & 0.008 & 1 & 0.051 & 1 & 0.011 & 1 & 0.064 & 1 \\
\hline Electricity \& Gas & 0.002 & 2 & 0.002 & 2 & 0.005 & 3 & 0.007 & 3 \\
\hline Total & 0.010 & & 0.054 & & 0.025 & & 0.095 & \\
\hline
\end{tabular}

Source: DOSM, Input-Output Table for 1991 \& 2000, Malaysia 


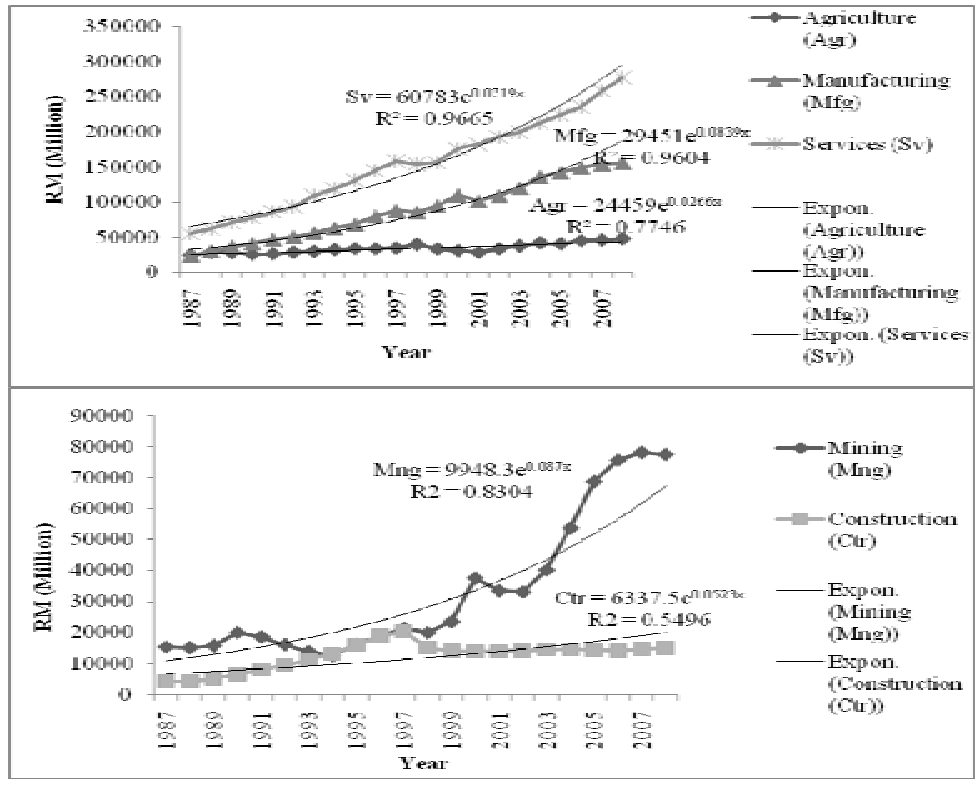

Figure 1. GDP by Sector (RM Million) Constant at 2000 Price

Source: DOSM, Annual National Account, Gross Domestic Product, 1987-2004 \& 2000-2008

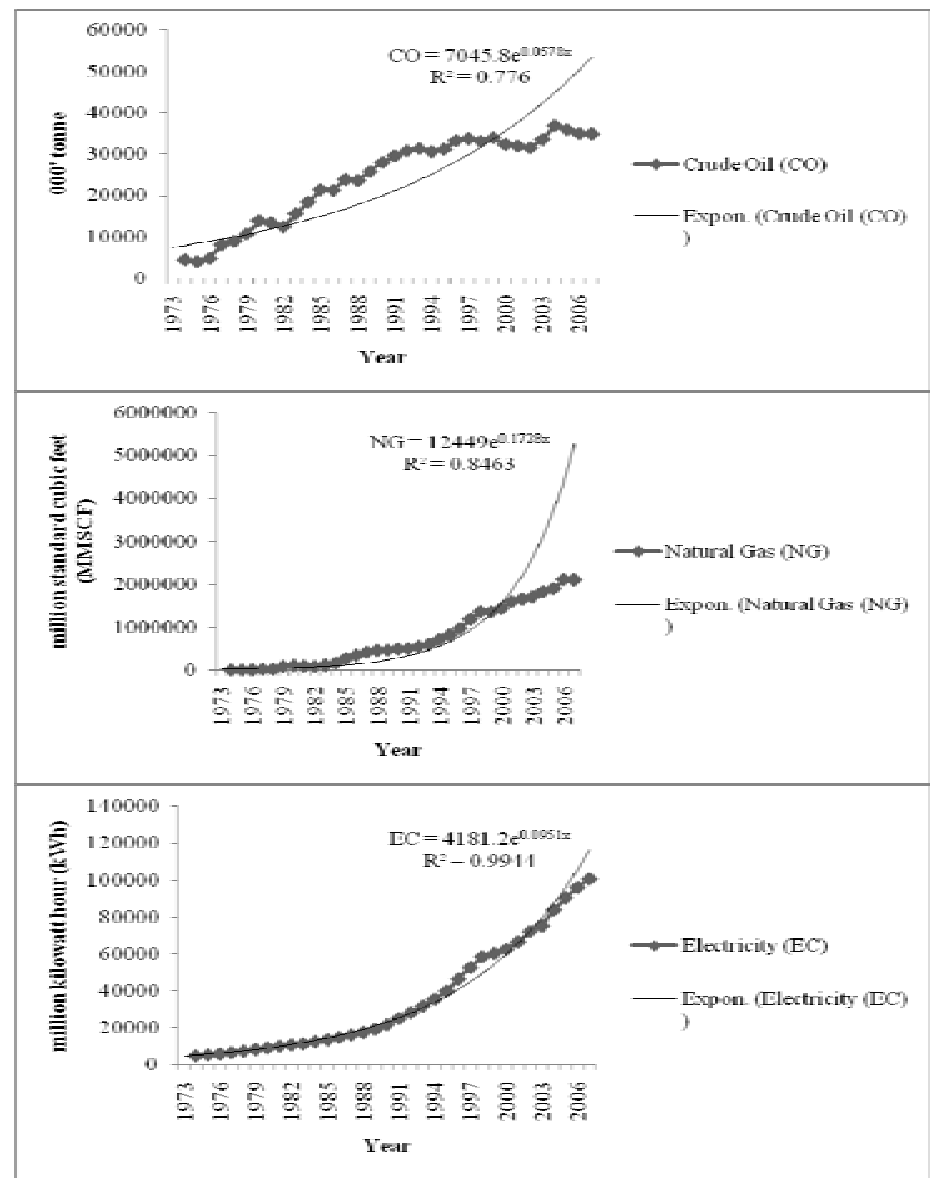

Figure 2. Crude Oil Production, Natural Gas Net Production, Electricity Generation

Source: DOSM (2007), Malaysia Economic Statistics - Time Series 


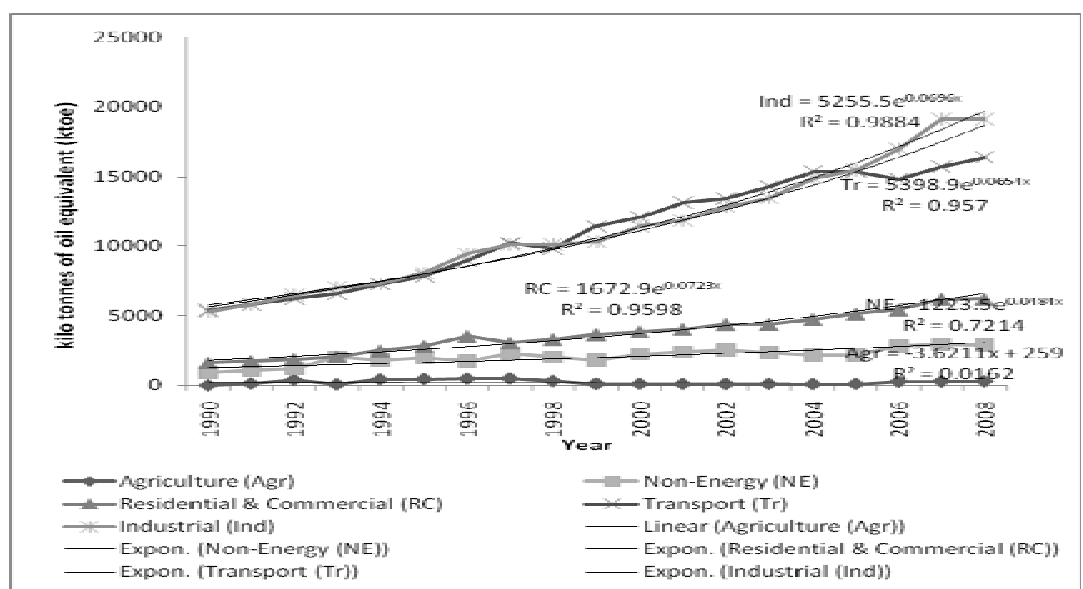

Figure 3. Energy Demand by Sector

Source: NEB (2008), Malaysia Energy Centre. 